\section{Wine tourism and hedonic experience: A motivation-based experiential view}

\author{
Johan Bruwer $\mathbb{D}$ \\ School of Marketing, Ehrenberg-Bass Institute for Marketing Science, University of \\ South Australia, Australia; Department of Management, Marketing and \\ Entrepreneurship, University of Canterbury, Christchurch, New Zealand
}

\section{Edith Rueger-Muck}

Department of Marketing, University of Applied Sciences Ludwigshafen on the Rhine, Germany
Tourism and Hospitality Research 2019, Vol. 19(4) 488-502 (C) The Author(s) 2018 Article reuse guidelines: sagepub.com/journals-permissions DOI: $10.1177 / 1467358418781444$ journals.sagepub.com/home/thr (SAGE

\begin{abstract}
This study adopts the experiential and more specifically a hedonic view of tourism consumption to examine the nature of wine tourist motivations in a wine region destination. It also determines the effect of destination factors such as the perceived characteristics of the wine region, previous visitation, buying behavior, and age generational cohorts. Information was obtained from a random sample of 513 visitors to the Barossa Valley Region in Australia. The most important destination characteristic is the regional landscape's scenic beauty. The strong impact of the landscape confirms an experiential research approach can yield valuable insights and that a memorable wine tourism experience does not only evolve inside a winery's cellar door. The wine tourism engagement decision is generally impulsive, and motivations guiding visitors' behavior predominantly hedonic in nature. Wine tourists are a highly attractive group of consumers who are well-educated, affluent, and eager to buy when they experience "pleasure."
\end{abstract}

\title{
Keywords
}

Motivations, hedonic experience, experiential approach, wine tourism, age generations

\section{Introduction}

Despite the rapidly changing environment, there is general consensus among tourism scholars that the consumption of tourism products possesses a predominantly hedonic component (Calver and Page, 2013; Gursoy et al., 2006; Hosany and Gilbert, 2010; Kim, 2014; Quadri-Felitti and Fiore, 2012). Not surprisingly, the research topic focus, from a hedonic perspective, has been quite wide ranging from examining it as a driver of travel expenses (Laesser and Crouch, 2006) to its role in re-patronizing behavior at a festival (Grappi and Montanari, 2011). It seems somewhat strange that, although it has gained strong attention and recognition among tourism researchers, so few have linked hedonism to the motivations of tourists, let alone to personal factors such as age generational cohorts.

The term "hedonism" comes from the ancient Greek for "pleasure" (Veenhoven, 2003). In the field of psychology, its central tenet is that pleasure seeking is a main motivator of human behavior. In general, pleasure is understood as including or is included in all pleasant feeling or experience: contentment, delight, ecstasy, elation, enjoyment, euphoria, exhilaration, exultation, gladness, gratification, gratitude, joy, liking, love, relief, satisfaction, tranquility, and so on (Veenhoven, 2003). Although wine consumption itself can be regarded as a hedonic experience (Bruwer and Alant, 2009), the special-interest field of wine tourism is no exception to the existence of a paucity of research on this topic (Quadri-Felitti and Fiore, 2012). Wine

\section{Corresponding author:}

Johan Bruwer, School of Marketing, Ehrenberg-Bass Institute for Marketing Science, University of South Australia, City West

Campus, North Terrace, Adelaide, SA 5001, Australia.

Email: johan.bruwer@unisa.edu.au 
tourism activity is an extension of the rather complex relationship between wineries, wine region, and the visitor. Engagement by people in wine tourism would therefore seem a logical search for a better acquaintance with the tourism product (Bruwer and Alant, 2009). The nature of wine tourism principally involves the indulging of the senses in the wine product and its immediate aesthetic surroundings and therefore an experiential (hedonically oriented) view of the consumption of wine tourism seems justified (Charters et al., 2009). Not surprising, the experiential approach to research study in wine tourism has been advocated (Charters et al., 2009; Chen et al., 2015; Dodd and Gustafson, 1997; Pikkemaat et al., 2009) but the evolvement of this approach in this field is still at an early stage. Little is known about the motivational forces that actually drive wine tourists to consumption of the tourism product and hence our study aims to provide further insights into this aspect.

Although what happens inside the cellar door of wineries is important, the broader location (winescape) and setting can be an equally important element in the total context of the business of wine tourism. Understanding what awareness wine tourists have of their physical environment and how it affects their behavior can therefore be utilized as a unique selling point of wine tourism. The setting is thus an important factor in the consumption of wine tourism. That is, the rural countryside where agriculture is normally practiced, vineyard landscape, cellar doors and facilities, and so on, in other words the "winescape" (Hall et al., 2000).

While the need for more consumer-based research is expressed in the literature (Getz and Brown, 2006), there is more specifically a need to better understand the characteristics and motives of wine tourists (Charters and Ali-Knight, 2002). Hence, our study has as its main premise that wine tourists are predominantly wine consumers looking for pleasurable (Pan et al., 2008) experiences to fulfill needs that are linked to more holistic leisure and holiday activities and not necessarily only to the wine consumption aspect itself. The overall aim of this research is to provide perspectives regarding the nature and importance of the hedonic nature of the wine tourism experience, not to test hypotheses to build theoretical frameworks. In terms of its contribution, our research enriches the knowledge base by being the first study in wine tourism to link destination attributes to visit motivations and the age generational cohorts concept from a hedonic perspective through an experiential research lens.

\section{Literature review}

The wine tourist is someone with a need to "connect" with the origin of the product through visitation of the location (wine region) where wine is produced. Wine tourism research has brought some salient factors and differences to light based on demographics (Charters and Ali-Knight, 2002; Getz and Brown, 2006) and destination analysis (Bruwer and Lesschaeve, 2012; Bruwer et al., 2013). Because such diversity of behavior exists, it is a challenge to understand the individual wine tourism experience. The importance of the hedonic and experiential consumption of wine tourism is strongly supported by Quadri-Felitti and Fiore (2012) in their work which adopts the experience economy perspective, as in Pine and Gilmore (1998). Our study adopts the experiential view of wine tourism originally advocated by Dodd and Gustafson (1997) and first applied in the wine tourism research field by Bruwer and Alant (2009). In the process, it provides some conceptual development of wine tourism experience, tourism consumption and, related hedonic behavior within the framework of the age generational aspect.

\section{Motivations of wine tourists}

It has been widely recognized that an understanding of the motivations that lead to travel decisions and tourism consumption is essential for the marketing of tourism destinations (i.e. Fodness, 1994; Goossens, 2000; Nicolau and Mas, 2006). Motivation has been described as a "need-induced tension" (Schiffman et al., 2011) that propels a person to do something about relieving the tension (Goossens, 2000) and forms the nexus of basic motivation theory (Fodness, 1994). The person (consumer) will therefore not buy something or be propelled to action leading to some form of consumption unless this state of need-induced tension arises. Moreover, an objective must be present for a need to be satisfied and for that to happen, an individual must be aware of the product or service (Goossens, 2000).

Gnoth (1997) reminds that the socio-psychological approach is the main source for explaining and predicting tourism behavior. Encapsulated therein is the functional approach to understanding tourist motivations which posits that the reason individuals hold certain attitudes is that these attitudes serve their psychological needs (Fodness, 1994). More specifically, Goossens (2000) distinguishes between "push" motivations (consumer dispositions such as needs, motives, and drives) and "pull" motivations (marketing stimuli such as destination characteristics, advertising, and services). He goes further to say that research on pleasure (hedonic) motivation should explore the relationship between push and pull factors and that emotional and experiential needs are relevant in pleasure seeking and choice behavior (p.302); 
a hedonic consumption view put forward earlier by Hirschman and Holbrook (1982).

Hirschman and Holbrook (1982) suggest that an interactionist perspective be adopted when exploring the hedonic motivations when tourists select a destination and consume the tourism products and/or services. Goossens (2000: 305) describes this in more specific terms stating that: "the push and pull factors melt together in the brain of the consumer, so to speak, and the individual is motivated, or not, to take advantage of the supply in the market." The combination of push-pull information and hedonic responses will therefore motivate tourists to plan a trip.

The intense social context of wine tourism behavior combined with the indulging of the senses have been confirmed in studies showing that people who engage in this activity, tend to be almost always accompanied by others (Bruwer and Alant, 2009; Byrd et al., 2016; Hall et al., 2000). Several researchers have confirmed that the primary motivations of wine tourists are "to taste" and "to buy wine" (Alant and Bruwer, 2004; Bruwer and Alant, 2009; Charters and Ali Knight, 2002). According to Byrd et al., (2016) the role of hedonic motivations that lead to wine tourism consumption cannot be excluded when analyzing their importance in affecting the winery. Hence, we propose that wine tourism lends itself to further exploration of the hedonic motivations that drive tourists to consumption, and that this is also reflected in their perception of the destination's imagery or winescape, particularly when examined from an experiential viewpoint as in Bruwer and Alant (2009).

Because of the rural setting in which wine tourism occurs, it is likely that environmental arousal is at the root of the motives of wine tourists to satisfy their needs. Environmental arousal is congruent with the hedonic motives of tourists. It should also be kept in mind that not all wine tourists are necessarily wine drinkers and therefore have wine-related motivations (Douglas et al., 2001). Other than to taste and buy wine, there are also "secondary" motivations such as learning about wine, socializing, being entertained, travelling in a rural setting, relaxation, and so forth that round off the experience (Bruwer and Alant, 2009; Getz and Brown, 2006; Getz et al., 1999).

A gap exists in the knowledge base in that little is known about the motivational forces that drive people to wine tourism consumption (Ravenscroft and van Westering, 2001), despite the fact that a motivational framework for cellar door research covering three dimensions highlights the interrelatedness of several aspects (Alant and Bruwer, 2004): the visitor profile, wine region imagery, and visit dynamic (first-time or repeat visitor). The existing literature also does not cover particularly well the link between visit motivations and the different age generations of tourists. The motivations relating to relaxation and time with family and friends may be more closely linked to the main and secondary destinations, as would be the demographic profile, prior travel experience, the trip profile, activities like cultural tourism, likes, environmental quality, and service quality satisfaction (McKercher and Wong, 2004). Moreover, motivations such as discovery and exploration are in the realm of the firsttime or repeat visitor dimension.

According to Nicolau and Mas (2006), most studies assume independence between tourist motivations and attributes of the tourism destination. This is also our approach in this study and hence we set research questions to explain the decisions through interaction of wine regional characteristics with the personal motivations of the tourist. In the process, we enrich the knowledge base by being the first study in wine tourism to simultaneously link destination attributes to visit motivations and the age generation concept.

\section{Age generational cohorts of tourists}

Generational age cohorts are groups of individuals characterized by their year of birth. An age generation typically refers to people born over a 15-20 year span, such as the Millennial generation (Pew Research Center, 2015). Despite their relative ease of measurement, generational age cohorts are one of the least understood marketing dynamics (MacDonald et al., 2013; Saliba et al., 2015). However, age generation descriptors such as Millennials, Generation-Xers and Baby Boomers are commonly used. The significance of such categorization is that each group shares a common history based on their life experiences of various factors such as prominent events, social norms, and expectations (Jackson et al., 2010). This common history among individuals within each generational cohort "produces unique values and behaviours that create similarities across consumers" (Noble et al., 2004: 1034). More specific to wine tourism, the belief is widely held that for the world wine market to grow, more young drinkers must be introduced to wine during the critical years in their early to midtwenties, during which they form many of their consumption habits for life (Bruwer, 2004, 2002; Higgins and Wolf, 2016; Saliba et al., 2015).

The age of an individual is one of the most common predictors of differences in attitudes and behavior. The age variable denotes two important characteristics about an individual: their place in the lifecycle and their membership of a cohort of individuals born during a similar time period (Pew Research Center, 2015). Researchers identify three separate effects 
that can produce differences between age generations: lifecycle or age effect, period effect (events and circumstances such as wars and broader social forces), and cohort effect (unique historical circumstances that members of an age cohort experience) (Dinas and Stoker, 2014). The commonly used current age generational cohorts are: Millennials (born after 1980), Generation-X (born 1965-1980), Baby Boomers (born 1946-1964), Silent Generation (born 1928-1945), and the Greatest Generation (born before 1928) (Pew Research Center, 2015).

It is important to note that age generational cut-offs are not an exact science and their boundaries are not arbitrary. Hence, generational cohorts are viewed by their timespan and there is no agreed upon formula for how long that timespan should be (Dimock, 2018). In the current study, we operationalized the age generational cohorts as follows:

Millennials (18-37 years old)

Generation-Xers (38-51 years old)

Baby Boomers Plus (52 years and older)

In our study, the Baby Boomers Plus group includes Baby Boomers (52-70 years old) plus the Silent Generation and Greatest Generation (older than 70 years) due to the fact that only $1.8 \%$ of respondents in our study belong to the latter two generational cohorts.

Whereas MacDonald et al. (2013) could not find support for the literature's predictions about generational cohorts and wine consumption, there remains ample evidence pointing to the contrary. For example, from a sensory perspective, the taste of wine is the most important factor in determining why people do or do not drink wine (Bruwer et al., 2012, 2013). Generally consumers' wine consumption increases with age peaking during the midlife stages before declining (Bruwer, 2014). Of special interest is the fact that Generation-Xers are willing to spend more on a bottle of wine, and make more winery visits than Millennials (Bruwer, 2004). It therefore makes sense to examine the relationship(s) between age generational cohorts and the motivations that drive them to visit cellar doors in the process engaging in wine tourism. We propose that wine tourists will have different motivations and view the tourism destination's regional characteristics differently across the age generations.

\section{Characteristics of the wine tourism destination}

The literature use the descriptors of "winescape" (Bruwer et al., 2016; Quintal et al., 2015) to denote a wine regional destination, place attachment
(Prayag and Ryan, 2011) to denote an emotional bond with a place, and terroir (Holland et al., 2014; Marzo-Navarro and Pedraja-Iglesias, 2009) which refers to a soil-specific site such as a vineyard within a wine region, interchangeably. In the current study, we use regional setting (winescape) as it has had broader appeal in the context of wine tourism.

The wine regional destination is an important factor in the consumption of wine tourism in that it is the rural countryside setting where agriculture is normally practiced and contains vineyards, landscape, cellar doors, tourist facilities, and so forth (in other words, the winescape) (Quintal et al., 2015). The winescape lends itself for wine tourists to indulge in experiences in sometimes aesthetically pleasing environments of both a natural and physical nature (Bruwer and Alant, 2009).

Destination image analysis has been a topic of much interest among tourism researchers but the actual impact of the natural environment on wine tourists has not received much attention in research although it is noted by visitors as a factor that impacts on their experience (Bruwer et al., 2016). To understand why people visit wine region destinations, it is important to determine the key attributes of the wine tourism experience. When doing so, it is necessary to examine the natural environment, namely the winescape, within which this experience takes place (Bruwer et al., 2016). Douglas et al., (2001: 313) feel that "wine tourism is influenced by the physical, social and cultural dimensions of the winescape and its components." Roberts and Sparks (2006) point out that winery visitors report that the setting attracted them and enhanced their experiences. Moreover, the landscape itself also forms part of the winescape in relation to wine tourism. Landscape can be viewed as having an inherent physical quality (Lothian, 1999) and having an aesthetic impact (Nohl, 2001).

The activity of tourists visiting winery cellar doors in a wine region destination is the essence of wine tourism (Gill et al., 2007). By virtue of its nature, the cellar door is also a tourism destination or place, and "places are the venues for tourism experiences" (Snepenger et al., 2007: 310). Core destination appeal includes features such as "attractive scenery, pleasant climate, moderately priced accommodation, easy to obtain information, well-signposted wine trails, and a variety of things to see and do" (Getz and Brown, 2006: 155). One of the tenets of our study is that wine tourism is the culmination of a number of unique experiences that include the surrounding environment, ambience, atmosphere, regional culture, and local wine and food. We focus on the hedonic elements of these unique experiences and highlight their importance to wineries and other tourism operators. 
The current study does not per se focus on destination loyalty but this aspect, often underpinned by the first-time versus repeat visitor metric, deserves some attention as it could play a role in the motivations that drive people to visit and revisit (McKercher and Tse, 2012; Opperman, 2000; Shani et al., 2012). Understanding tourists' revisit motivations is generally regarded as a strong predictor of their future behavior (Assaker and Hallak, 2013). Whereas repeat visitors were found to be the majority of all tourists at several destinations (Shani et al., 2012), a relatively high incidence of first-time visitation in wine tourism has been confirmed in diverse studies in Australia (Bruwer et al., 2013; Famularo et al., 2010), South Africa (Bruwer and Alant, 2009) and Canada (Bruwer and Lesschaeve, 2012). Some reasons for this could be related to previous positive experience, product affinity, and brand loyalty (Mitchell and Hall, 2004).

\section{Hedonic orientation and experiential perspective of wine tourism}

Following Hirschman and Holbrook's (1982) seminal study which advocated greater attention to hedonic consumption, and hence to the emotional response to products, it is well recognized that consumer choice is driven by both utilitarian and hedonic considerations (i.e. Dhar and Wertenbroch, 2000), meaning they are not mutually exclusive. The definitions of hedonic and utilitarian products are useful in distinguishing between these attitude components: "hedonic goods are those ones whose consumption is primarily characterized by an affective and sensory experience of aesthetic or sensual pleasure, fantasy, and fun" (Hirschman and Holbrook, 1982: 92); while "utilitarian goods are ones whose consumption is more cognitively driven, instrumental, and goal oriented and accomplishes a functional or practical task" (Dhar and Wertenbroch, 2000: 61). Hedonism is one of 10 human value types (Schiffman et al., 2011). In essence, the hedonism value type involves pleasure and sensuous gratification for oneself. Laesser and Crouch (2006) used as rationale hedonism as the driver of travel expenses to segment the market. A good example is a wine tourism "product" in the form of a wine festival held within the ambit of a wine region (Grappi and Montanari, 2011; Gursoy et al., 2006).

Tourism scholars have long recognized that the consumption of tourism products possesses a predominantly hedonic component (Bruwer and Alant, 2009; Chen et al., 2016). The existence of this emotional (experiential) component is consistent with the premise that the primary purpose of tourism product consumption is to pursue pleasurable or hedonic experiences (Kim, 2014; Meng and $\mathrm{Xu}, 2012$; Pikkemaat et al., 2009). Hence, the connection between the hedonic perspective and wine tourism seems a logical one. For example, "in the hedonic consumption view, the high interest and involvement generated by aesthetic products is strongly emphasized" (Spangenberg et al., 1997: 236). Following the recognition by consumer behavior researchers of the significance of the hedonic nature of the purchases of many goods and services in the 1980s (i.e. Holbrook and Hirschman, 1982) the "experiential view" of consumption emerged. In contrast to the rational "problem-solving approach" the "experiential view" recognized "the special nature of products and services that have a hedonic component, such as wine, leisure activities and pleasure travel" (Hall et al., 2000: 129; Hosany and Gilbert, 2010). As far as buying wine is concerned, one view is that this is a utilitarian motive (i.e. Hall et al., 2000), but wine tourism studies (i.e. Bruwer and Alant, 2009) have repeatedly referred to it as a motivation in the pursuit of hedonism. Realistically, one has to buy wine to enjoy its taste and hence buying it is inextricably associated with tasting the wine.

The experiential view of consumption is particularly well outlined in the literature by Pine and Gilmore (1998) and subsequently further developed by Oh et al., (2007). Pine and Gilmore (1998) have the view that all consumer experiences are taking place in one person's mind and are therefore very personal and no two people would have the same experience. It is also recognized that the tourism experience is not limited to a particular site or attraction and that several elements of the wider experience of a region will impact the on-site experience (Johnson, 1998).

Hall et al. (2000) attributed the dearth of experiential research on wine tourists to the fact that little or no "baseline" information exists. Before theoretical foundations can be developed with some confidence, baseline research on this topic is thus needed (Bruwer and Alant, 2009; Carlsen and Boksberger, 2015; Charters et al., 2009) which is what the current study strives to provide. Few wine tourism studies have focused on the total experience aspect, in other words, what reasons other than the obvious "to taste and buy wine" actually motivated them to visit (Asero and Patti, 2011; Chen et al., 2016; Chen et al., 2015; Pikkemaat et al., 2009).

Finally, whereas the psychological construct "involvement" has been linked to wine tourism (Galloway et al., 2008), wine tourists have also been categorized in terms of lifestyle variables. At the broadest level, a distinction has been made between the "specialist wine tourist" and the "generalist wine tourist" (i.e. Carlsen et al., 1998). While the specialist 
wine tourist's primary motivation for visiting a wine region is wine-related, the generalist wine tourist visits for primarily other reasons such as holidaying. Our study used this broad distinction to infer relationships with their motivations to consume wine tourism products and services.

Based on the previous discussion and to assist with the operationalization of the study, the following research questions were formulated:

- What are the motivational reasons for winery visitation by wine tourists?

- What are the visitation dynamics of wine tourists to winery cellar doors in terms of their age generational cohort membership and other factors?

- What are the consumption (buying) outcomes of wine tourists at the cellar doors and what is the extent of their pre-visit relationship with the winery's products?

- What is the predominant nature of the perceived regional characteristics of a wine region from the viewpoint of its wine tourists from a hedonic and age generational cohort membership perspective?

\section{Methodology}

The primary data collection instrument was a purpose-designed highly structured questionnaire. The questionnaire had 25 questions in total, mostly close-ended. The sampling frame was the visitors to cellar doors within the Barossa Valley Wine Region (BVWR) in South Australia. Barossa Valley is Australia's premier wine region and located only a one-hour drive from the Adelaide CBD, South Australia's capital city. The cellar doors were chosen to reflect a broad range of sizes of winery/cellar door businesses to obtain a wide as possible range of visitors and have an acceptable degree of fit with the universum of wineries. A time-based random sampling design was used, with no quotas imposed relating to any characteristic of the visitors.

The research questionnaires were administered at the cellar doors where data collection took place during a 6-8 week period in 2016. Cellar door staff were given clear instructions on ensuring randomness when recruiting visitors to participate in the survey. For example, only one respondent from a household could participate in the survey and was intercepted randomly upon arrival during different times of the day and days of the week, but waiting until the identified person was ready to depart. This ensured that visitors had first enjoyed the wine tourism experience before participating in the research. The amount of time needed to complete the questionnaire was explained and respondents given an assurance of complete confidentiality regarding their personal information. On average, respondents managed to answer questionnaires within an 8-12 minute time period. The self-administered surveys were completed in situ at the cellar doors, ensuring that information pertaining to the visit experience was still fresh in the minds of the respondents.

Using cellar door staff to administer the surveys also had the advantages of first establishing a relationship of trust with the visitor before completion of the questionnaires in a relaxed atmosphere, and of course a considerable saving on the cost of data collection. Incentives were offered in the form of entry in a lucky draw for a case of the region's best wine. The final sample size is 513 respondents giving a $81 \%$ response rate. The data were entered and manipulated in the SPSS 24 statistical software programme and information compared and extracted in accordance with the nature of the data collected.

\section{Results}

\section{Demographic characteristics of the region's wine tourists}

The results in Table 1 show an almost equal split between males $(51 \%)$ and females $(49 \%)$. Visitors were categorized in three age generational cohorts according to previous research (Bruwer, 2004; Bruwer and Alant, 2009) namely 18-37 years of age ("Millennials"), "Generation-Xers" between 38-51 years and 52 years and older ("Baby Boomers Plus"). The largest group in the sample represents Generation-Xers (42\%), followed by Millennials (37\%) and Baby Boomers Plus (21\%).

Among female tourists, there are slightly more firsttime visitors $(47 \%)$ to the wine region than among male tourists $(40 \%)$, whereas more male tourists visited the region as repeat visitors $(60 \%)$ than female tourists (53\%). A small majority of visitors thus have previous visit experience of the destination.

Around one-third of visitors originate from the region's home state of South Australia (36\%) while the remaining $64 \%$ are from out-of-state which in this study means from the rest of Australia and overseas countries. The educational status of the wine tourists is quite high in that over three quarters (76\%) hold a post-secondary qualification. Male visitors have a higher education level than female visitors: $50 \%$ of the male tourists have an undergraduate post-secondary qualification, and $29 \%$ a postgraduate qualification. By comparison, $44 \%$ of female visitors have an undergraduate post-secondary qualification and $27 \%$ a postgraduate qualification. The annual household income is relatively high in that $66 \%$ of 
Table 1. Demographic characteristics and visitor segments of Barossa wine region's visitors.

\begin{tabular}{|c|c|c|c|}
\hline Characteristic & $\begin{array}{l}\text { Female }(\%) \\
(n=251)\end{array}$ & $\begin{array}{l}\text { Male }(\%) \\
(n=262)\end{array}$ & $\begin{array}{l}\text { Total }(\%) \\
(n=513)\end{array}$ \\
\hline \multicolumn{4}{|l|}{ Age group and age generational cohort: } \\
\hline 18-37 year old (Millennials) & 38.6 & 34.7 & 36.6 \\
\hline 38-51 year old (Generation-Xers) & 45.0 & 38.9 & 41.9 \\
\hline $52+$ years old (Baby Boomers Plus) & 16.4 & 26.4 & 21.5 \\
\hline \multicolumn{4}{|l|}{ Origin (place of permanent residence): } \\
\hline In-State (South Australia-SA) & 35.9 & 36.3 & 36.1 \\
\hline Out-of-State (rest of Australia and overseas) & 64.1 & 63.7 & 63.9 \\
\hline \multicolumn{4}{|l|}{ Education level: } \\
\hline No post-secondary qualification & 28.6 & 20.2 & 24.4 \\
\hline Undergraduate post-secondary qualification & 44.3 & 50.0 & 47.1 \\
\hline Postgraduate qualification & 27.1 & 29.8 & 28.5 \\
\hline \multicolumn{4}{|l|}{ Destination visitor segment: } \\
\hline First-time visitor & 47.0 & 40.1 & 43.5 \\
\hline Repeat visitor & 53.0 & 59.9 & 56.5 \\
\hline \multicolumn{4}{|l|}{ Number of persons living in household: } \\
\hline Persons under 18 years old & 0.33 & 0.40 & 0.37 \\
\hline Persons 18 years and older & 2.12 & 2.22 & 2.17 \\
\hline Persons $\geq 18$ years old who drink wine & 1.88 & 1.99 & 1.94 \\
\hline Persons in household (total size) & 2.45 & 2.62 & 2.54 \\
\hline \multicolumn{4}{|l|}{ Annual household income a level: } \\
\hline$\leq \$ 25,000$ per year & 3.6 & 3.3 & 3.5 \\
\hline$\$ 25,001-\$ 50,000$ per year & 14.4 & 10.7 & 12.5 \\
\hline$\$ 50,001-\$ 75,000$ per year & 21.6 & 17.4 & 19.4 \\
\hline$\$ 75,001-\$ 100,000$ per year & 19.8 & 23.1 & 21.6 \\
\hline$\$ 100,001-\$ 150,000$ per year & 24.8 & 24.0 & 24.3 \\
\hline$\$ 150,001-\$ 200,000$ per year & 8.1 & 7.4 & 7.8 \\
\hline$\$ 200,000+$ per year & 7.7 & 14.1 & 10.9 \\
\hline Annual household income (median): & $\$ 99,090$ & $\$ 110,124$ & $\$ 104,849$ \\
\hline
\end{tabular}

${ }^{\mathrm{a}}$ Australian \$.

the sample population had an annual household income above the national average of AU $\$ 66,820$ (Australian Bureau of Statistics, 2015). The wine tourists originate from small households with an average size of 2.54 persons with few dependent children living in the household ( 0.37 persons are under 18 years old). The number of persons in the household 18 years and older who drink wine is 1.94 underlining the fact that it is largely a shared (social) activity. Hence the region's wine tourist profile depicts a well-educated, affluent, relatively mobile person with few dependent children and small households, often with previous visit experience, originating from outside the home state and therefore is someone who embraces long travel distances to visit the destination.

\section{Wine region visitor groupings}

There are significant differences between in-state and out-of-state visitors as far as first-time and repeat visitation of the region is concerned. Most first-time visitors are from out-of-state (89\%) with only $11 \%$ originating from South Australia. Looking at repeat visitors, the ratio is a bit more "balanced" in that $55 \%$ are from South Australia versus $45 \%$ from outof-state. On average, in-state visitors have made 10.2 visits to the BVWR, while out-of-state visitors have visited the region much less frequently with an average of 4.3 visits $\left(F=63.624, p=.000^{\star \star}\right.$ at 0.1 level). This is not surprising as out-of-state visitors have to travel a longer distance to the wine region (see Table 2).

\section{Timing of final decision to visit the wine region}

Table 3 shows the time period wine tourists indicated within which they made their final decision to visit the BVWR. The length of the planning phase for visit decision-making is of interest as it could be an indicator of the hedonic aspect of the wine tourism experience. Similar to previous studies (i.e. Alant and Bruwer, 2010; Bruwer and Alant, 2009; Bruwer and Thach, 2013) tourists indicated that their decision was 
Table 2. Wine region visitors' groupings by origin.

\begin{tabular}{|c|c|c|c|c|c|}
\hline Visitation dynamic & $N=513$ & $\%$ & Origin & $n$ & $\%$ \\
\hline \multirow[t]{3}{*}{ First-time visitors } & 223 & 43.5 & In-state & 24 & 10.8 \\
\hline & - & - & Out-of-State & 199 & 89.2 \\
\hline & - & - & - & 223 & 100.0 \\
\hline \multirow[t]{3}{*}{ Repeat visitors } & 290 & 56.5 & In-state & 161 & 55.5 \\
\hline & - & - & Out-of-State & 129 & 44.5 \\
\hline & - & - & - & 290 & 100.0 \\
\hline \multirow[t]{2}{*}{ Number of visits made ${ }^{a}$} & - & - & In-state & 10.16 visits $^{a}$ & \\
\hline & - & - & Out-of-State & 4.33 visits & \\
\hline
\end{tabular}

${ }^{\mathrm{a}}$ Significant at .01 level $\left(\mathrm{F}=63.624 ; \mathrm{Sig}=.000^{\mathrm{b}}\right)$.

Table 3. When the final decision was made to visit the wine region.

\begin{tabular}{|c|c|c|c|c|c|c|}
\hline & \multirow{2}{*}{$\begin{array}{l}\text { Total study } \\
\%\end{array}$} & \multirow{2}{*}{$\begin{array}{l}\text { Millennials } \\
\%\end{array}$} & \multirow{2}{*}{$\begin{array}{l}\text { Gen-Xers } \\
\%\end{array}$} & \multirow{2}{*}{$\begin{array}{l}\text { Boomers Plus } \\
\%\end{array}$} & \multicolumn{2}{|c|}{ Test statistic } \\
\hline & & & & & $\chi^{2}$ & Sig \\
\hline As I/we were passing by & 2.7 & 3.2 & 1.9 & 3.6 & 1.104 & .576 \\
\hline This morning & 10.1 & 10.6 & 10.7 & 8.2 & .588 & .745 \\
\hline During the last 24 hours & 18.9 & 24.5 & 17.2 & 12.7 & 6.936 & $.031^{\mathrm{a}}$ \\
\hline During the last week & 18.7 & 16.0 & 20.9 & 19.1 & 1.644 & .440 \\
\hline During the last month & 27.3 & 25.5 & 30.2 & 24.6 & 1.649 & .439 \\
\hline During the last three months & 10.5 & 11.2 & 9.3 & 11.8 & .620 & .734 \\
\hline During the last six months & 9.2 & 8.5 & 7.9 & 12.7 & 2.183 & .336 \\
\hline During the last $7-12$ months & 1.0 & 0.5 & 1.9 & - & 3.212 & .201 \\
\hline More than 12 months ago & 1.6 & - & - & 7.3 & 29.773 & $.000^{\mathrm{b}}$ \\
\hline Total & 100.0 & 100.0 & 100.0 & 100.0 & - & - \\
\hline
\end{tabular}

Significant at .05 level.

bSignificant at .01 level.

made with very little advance planning. This is reflected in the fact that $32 \%$ of them made this decision during the 24-hour period immediately preceding the visit, $50 \%$ during the last week, and $78 \%$ during the last month. Very few wine tourists planned their trip to the region more than a year in advance $(2 \%)$. These results could be indicative of the spurious side of the hedonic nature of wine tourism.

Millennials indicated the significantly shortest decision-making time period among the age generations with $38 \%$ making their decision within the last 24 hours or less, followed by Generation-Xers (30\%) and Baby Boomers Plus (25\%) $\left(\chi^{2}=6.936, p=.031^{\star}\right.$ at 0.05 level). The Baby Boomers Plus are the age group with the longest planning period with $7 \%$ reporting they made their final decision more than 12 months ago $\left(\chi^{2}=29.773, p=.000^{\star \star}\right.$ at .01 level $)$. Yet, despite small group differences, the final visit decision of the wine region was fairly spontaneous or even unplanned. Hence, this spontaneous character of decision-making can be seen as an indicator of the hedonic character of the wine tourism experience.

\section{Main purpose of visit to wine region}

The research also determined the main purpose of visiting the BVWR by the wine tourists (Table 4). From an overall viewpoint tourists indicated three dominant reasons for their visit. Wine tourism ranked first $(42 \%)$, followed by holiday $(35 \%)$ and visit friends and relatives $(9 \%)$. All other reasons for visiting had values below 5\%. Among the top three purposes of the visit, there are indicators of concentration among the age generational cohorts in that in the case of wine tourism Millennials (42\%) were in the majority, while Baby Boomers Plus (41\%) dominated holidaying and Generation-Xers (11\%) the visiting of friends and relatives. The underlying reasons for these results were not probed.

Based on the main purposes of the visit, we distinguish between so-called "specialists" (those who gave wine tourism as main purpose of their visit) and "generalists" (those who did not give wine tourism as main purpose of their visit). We propose that wine tourism specialists have different motivations and view the destination region's characteristics differently across the age generational cohorts. These 
assumptions are tested and further discussed in the sub-section on the perception of regional characteristics that follows later.

\section{Motivations for visiting the winery cellar door}

Table 5 shows a rank ordering of respondents' visit reasons of the specific winery cellar door in the regional destination where they were intercepted and interviewed. Visitors were given 15 different motivations sourced from the literature (i.e. Alant and Bruwer, 2004; Bruwer et al., 2013) to choose from and had to rank the ones that applied to them in order of importance. Note that in Table 5, the incidence percentage measures how many people from the total sample indicated that a specific motivation was relevant to them. This is necessary because not all wine tourists have the same motivations for visiting. As far as the rating (in brackets) is concerned, it is an importance rating on a five-point scale to rate the top five motivations in order of importance and in some cases, it shows that there is a dissonance between incidence and importance rating. Among the top five motivations, respondents indicated "taste wine" $(65 \%)$, "buy wine" $(52 \%)$, "experience the atmosphere" (45\%), "learn more about wine" (39\%) and "find a unique wine" (38\%). This reconfirms that the two main motivations and thus core activities in the wine tourism experience are tasting and buying of wine (i.e. Bruwer and Alant, 2009; Bruwer et al., 2013). For all age generational cohorts "taste wine" was the top reason to visit the winery, while Millennials and Generation-Xers ranked "buy wine"

Table 4. Main purpose of visit to wine region.

\begin{tabular}{|c|c|c|c|c|c|}
\hline \multirow{2}{*}{ Main purpose } & \multicolumn{2}{|c|}{ Total study } & \multirow{2}{*}{$\begin{array}{l}\text { Millennials } \\
\%\end{array}$} & \multirow{2}{*}{$\begin{array}{l}\text { Gen-Xers } \\
\%\end{array}$} & \multirow{2}{*}{$\begin{array}{l}\text { Boomers Plus } \\
\%\end{array}$} \\
\hline & $n$ & $\%$ & & & \\
\hline Wine tourism & 215 & 41.9 & 46.8 & 41.3 & 34.5 \\
\hline Holiday & 179 & 34.9 & 32.4 & 34.0 & 41.0 \\
\hline Visit friends or relatives & 45 & 8.8 & 5.9 & 11.1 & 9.1 \\
\hline Attend Barossa vintage festival & 21 & 4.1 & 3.7 & 2.8 & 7.3 \\
\hline Business/conference & 20 & 3.9 & 2.7 & 5.6 & 2.7 \\
\hline Recreation (sport or hobby) & 13 & 2.5 & 3.7 & 1.4 & 2.7 \\
\hline Just passing through & 11 & 2.1 & 0.5 & 3.3 & 2.7 \\
\hline Special occasion (wedding/birthday) & 9 & 1.8 & 4.3 & 0.5 & - \\
\hline Total & 513 & 100.0 & 100.0 & 100.0 & 100.0 \\
\hline
\end{tabular}

Table 5. Motivations for visiting the winery cellar door (Incidence). ${ }^{a}$

\begin{tabular}{|c|c|c|c|c|c|c|}
\hline & $\begin{array}{l}\text { Total study } \\
\%\end{array}$ & $\begin{array}{l}\text { Millennials } \\
\%\end{array}$ & $\begin{array}{l}\text { Gen-Xers } \\
\%\end{array}$ & $\begin{array}{l}\text { Boomers Plus } \\
\%\end{array}$ & $\chi^{2}$ & Sig \\
\hline Taste wine & $64.5(1)$ & 75.0 (1) & $64.7(1)$ & $46.4(1)$ & 24.874 & .206 \\
\hline Buy wine & $52.1(2)$ & $61.7(2)$ & $51.2(2)$ & $37.3(3)$ & 30.584 & .166 \\
\hline Experience the atmosphere & $45.4(3)$ & $46.3(5)$ & $48.4(3)$ & $38.2(2)$ & 28.651 & .155 \\
\hline Learn more about wine & $39.0(4)$ & $50.5(3)$ & $34.4(5)$ & $28.2(5)$ & 15.947 & .818 \\
\hline Find a unique wine & $37.8(5)$ & $47.3(4)$ & $36.7(4)$ & 23.6 & 26.688 & .319 \\
\hline Have a day out & 34.3 & 45.7 & 33.0 & 17.3 & 57.561 & $.000^{\mathrm{b}}$ \\
\hline Entertain myself and/or others & 30.2 & 36.7 & 30.7 & 18.2 & 31.035 & .153 \\
\hline Rural setting & 28.1 & 28.2 & 27.4 & $29.1(4)$ & 35.007 & .170 \\
\hline Eat at winery's restaurant & 23.6 & 21.8 & 23.7 & 26.4 & 44.903 & $.012^{c}$ \\
\hline Purchase this winery's merchandise & 23.0 & 20.7 & 27.0 & 19.1 & 47.912 & $.011^{\mathrm{c}}$ \\
\hline Socialize with others & 21.8 & 22.3 & 24.7 & 15.5 & 44.362 & $.032^{\mathrm{c}}$ \\
\hline Find information & 21.3 & 22.9 & 22.8 & 15.5 & 41.300 & $.029^{c}$ \\
\hline Meet the winemaker & 16.2 & 20.7 & 15.3 & 10.0 & 44.444 & $.043^{c}$ \\
\hline Go on a winery tour & 14.8 & 19.7 & 13.0 & 10.0 & 29.530 & .386 \\
\hline Have barbeque or picnic & 13.3 & 18.1 & 10.7 & 10.0 & 56.749 & $.002^{\mathrm{b}}$ \\
\hline
\end{tabular}

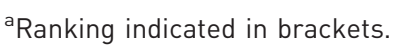

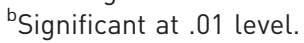

'Significant at .05 level. 
second, whereas Baby Boomers Plus ranked it third. Moreover, there are significant differences between the age generational cohorts regarding the importance attached to some of the visit reasons. For example, Millennials are significantly more inclined to want a day out $\left(\chi^{2}=57.561, p=.000^{\star \star}\right.$ at .01 level $)$, have a barbeque or picnic $\left(\chi^{2}=56.749, p=.000^{\star \star}\right.$ at .01 level), or meet the winemaker $\left(\chi^{2}=44.444\right.$, $p=.043^{\star}$ at .05 level) than Generation-Xers or Baby Boomers Plus, etc. These could be indicators, other than the tasting and buying of wine, of hedonic motivations and pursuits.

The findings in Table 5 further underline the fact that the top three motivations for visiting a winery cellar door namely "taste wine," "buy wine," and "experience the atmosphere" are of a hedonic nature. The motivations elicited in our study are very similar to the findings of a study by Bruwer and Alant (2009) about wine tourists in a South African wine region. From an overall viewpoint, we conclude that the motivations behind the visit to a winery cellar door are strongly hedonic in nature.

\section{Wine buying outcomes at the winery cellar door}

Next, we compare actual behavior with respondents' stated motivations. We use actual wine buying behavior during the visit experience as dependent variable and compare it with wine buying as a motivational factor and find that a strong correlation (Pearson $r=0.154^{\star}, p=0.12$ at .05 level exists) (not shown in tables). Hence a relationship between a stated core wine tourism motivational factor and actual behavior directly relating to that motivation does exist. In Table 6 , we see that $49 \%$ of respondents bought wine compared with $52 \%$ who gave that as a motivation for the visit (Table 5). We also measured prior awareness and actual experience of the wine brand (Table 6) as possible indicator of actual buying behavior during the wine tourism visit finding that $23 \%$ of the visitors had this prior connection with the brand.
This means that most tourists made their buying decision quite spontaneously and reflects a degree of impulsive buying behavior driven by motivations that are probably hedonic in nature. Interestingly, while this is highest among Millennials (28\%) and lowest among Baby Boomers Plus (17\%), the results for actual buying are the reverse with Baby Boomers Plus $(52 \%)$ showing a higher incidence of buying than Millennials (43\%). The highest buying incidence, however, occurred among GenerationXers (54\%).

Upon examining and comparing the buying metrics, it is clear that Baby Boomers Plus buy more wine (4.0 bottles) and spend more thereon ( $\$ 68.15)$ than either of the other age generations. This is consistent with previous research findings that in general older age groups consume more wine (i.e. Bruwer et al., 2012; Bruwer, 2004; Saliba et al., 2015) as they often are in a better financial situation than younger ones. Despite small differences among the age groups, results were not significant at either a .05 or 0.1 level. Interestingly, Millennials had the highest spend per bottle $(\$ 22.52)$ of any age generational cohort, which is perhaps an indicator of higher risk perception. The reasons for these answers were not probed in this study and could be the focus of future research

\section{Wine regional characteristics as perceived by visitors}

As the final step in examining the hedonic basis of the wine tourism experience, we look at the tourists' perception of the regional characteristics or winescape of the tourism destination and how this perception differs between age generations and wine tourism specialists and generalists. Table 7 displays the regional imagery of the Barossa Valley wine region in terms of tourists' perceived regional characteristics. We used a free-form approach to obtain these by asking them to mention the region's main characteristics in their own words. This elicited 1525 responses in total which

Table 6. Wine buying outcomes at the winery cellar door. ${ }^{a}$

\begin{tabular}{|c|c|c|c|c|c|c|c|c|}
\hline \multirow[b]{2}{*}{ Bought wine } & \multicolumn{2}{|c|}{ Total study } & \multicolumn{2}{|c|}{ Millennials } & \multicolumn{2}{|c|}{ Generation-Xers } & \multicolumn{2}{|c|}{ Boomers Plus } \\
\hline & Yes & No & Yes & No & Yes & No & Yes & No \\
\hline Cellar door & $49.1 \%$ & $50.9 \%$ & $42.6 \%$ & $57.4 \%$ & $53.5 \%$ & $46.5 \%$ & $51.8 \%$ & $48.2 \%$ \\
\hline Retail store or restaurant prior & $22.6 \%$ & $77.4 \%$ & $27.7 \%$ & $72.3 \%$ & $20.9 \%$ & $79.1 \%$ & $17.3 \%$ & $82.7 \%$ \\
\hline Number of bottles (mean) & 2.97 & & 2.12 & & 3.18 & & 4.01 & \\
\hline Total amount spent on wine & $\$ 56.45$ & & $\$ 47.75$ & & $\$ 58.08$ & & $\$ 68.15$ & \\
\hline Price paid per bottle ${ }^{b}$ & $\$ 19.01$ & & $\$ 22.52$ & & $\$ 18.26$ & & $\$ 17.00$ & \\
\hline
\end{tabular}

${ }^{\mathrm{a} E x c h a n g e ~ r a t e ~ a t ~} 17$ March 2017: $\$ \cup S 1.00=\mathrm{AU} \$ 0.76$.

${ }^{\mathrm{b}}$ No significant differences at either .05 level or .01 level. 
Table 7. Wine regional characteristics as perceived by visitors.

\begin{tabular}{|c|c|c|c|}
\hline & $\begin{array}{l}\text { Description of characteris- } \\
\text { tic/element }\end{array}$ & $n$ & $\%$ \\
\hline 1 & $\begin{array}{l}\text { Scenery and landscape, views, } \\
\text { hillsides, horizons, } \\
\text { vegetation, etc. }\end{array}$ & 228 & 44.4 \\
\hline 2 & $\begin{array}{l}\text { Wine quality, value, price, etc. } \\
\text { positive references }\end{array}$ & 206 & 40.2 \\
\hline 3 & $\begin{array}{l}\text { Wineries/wine estates, quality } \\
\text { features, facilities, variety of } \\
\text { small to large }\end{array}$ & 140 & 27.3 \\
\hline 4 & $\begin{array}{l}\text { Ambience of region, tranquility, } \\
\text { rural character, clean, } \\
\text { great climate }\end{array}$ & 139 & 27.1 \\
\hline 5 & $\begin{array}{l}\text { Restaurants great, food quality } \\
\text { excellent, German cuisine }\end{array}$ & 133 & 25.9 \\
\hline 6 & $\begin{array}{l}\text { Heritage and history, German } \\
\text { culture prevalent }\end{array}$ & 120 & 23.4 \\
\hline 7 & $\begin{array}{l}\text { People friendly, local hospitality } \\
\text { great, community spirit }\end{array}$ & 102 & 19.9 \\
\hline 8 & $\begin{array}{l}\text { Vineyards/grape growing focus, } \\
\text { cultivated appearance }\end{array}$ & 74 & 14.4 \\
\hline 9 & $\begin{array}{l}\text { Wine tastings and wine tours } \\
\text { well organized, good facilities }\end{array}$ & 64 & 12.5 \\
\hline 10 & $\begin{array}{l}\text { Tourism infrastructure high } \\
\text { standard, well developed }\end{array}$ & 63 & 12.3 \\
\hline 11 & $\begin{array}{l}\text { Quaint towns and buildings with } \\
\text { nice gardens, well maintained }\end{array}$ & 55 & 10.7 \\
\hline 12 & $\begin{array}{l}\text { Reputation/brand name of the } \\
\text { region, famous/well-known }\end{array}$ & 54 & 10.5 \\
\hline 13 & $\begin{array}{l}\text { Service staff knowledgeable, } \\
\text { professional and friendly }\end{array}$ & 47 & 9.2 \\
\hline 14 & $\begin{array}{l}\text { Accessibility of wineries and } \\
\text { proximity to Adelaide }\end{array}$ & 46 & 9.0 \\
\hline 15 & $\begin{array}{l}\text { Variety of activities and things to } \\
\text { see and do available }\end{array}$ & 37 & 7.2 \\
\hline 16 & $\begin{array}{l}\text { Cottage industries-bakeries, } \\
\text { butcheries, fruit, etc. }\end{array}$ & 17 & 3.3 \\
\hline
\end{tabular}

${ }^{a} X=1525 / 513=2.97$ regional characteristics/elements per respondent. equate to 2.97 regional characteristics per person on average. The responses are summarized in 16 different characteristics/elements in Table 7.

As in similar studies (i.e. Bruwer and Alant, 2009; Bruwer et al., 2016; Bruwer and Lesschaeve, 2012) respondents named the "scenery and landscape" as the dominant factor $(44 \%)$. The association of the region with "wine quality" (40\%), "wineries/wine estates quality features" (27\%), ambience of the region $(27 \%)$, and "restaurants with excellent food quality and German cuisine" (26\%) represent the remainder of the top five regional characteristics. This finding supports our proposition that wine tourists seek experiences predominantly hedonic in nature as reflected in their perception of the region's winescape.

\section{Top five wine regional}

\section{9 characteristic categories}

\section{- Visitor age generational cohorts}

Table 8 shows that all age generations indicated the same top five wine regional characteristics contained in Table 7, whereas there are slight differences between the age generations none of them is significant at either 0.5 or 0.1 level and differences are, in fact, quite small. We therefore conclude that the way tourists perceive a wine region's characteristics does not differ much depending on their age generation.

- Visitor age generational cohorts and wine tourism specialists versus generalists

Finally, Table 9 exhibits the top five regional characteristic categories according to age generational cohorts and the distinction between specialist and generalist wine tourists. Results show that for all age generation segments the top two characteristics of the BVWR are "scenery and landscape" followed by "wine quality". Only the generalists among the

Table 8. Top 5 wine regional characteristic categories-Visitor age generation segments.a

\begin{tabular}{|c|c|c|c|c|c|}
\hline & Description of characteristic & $\begin{array}{l}\text { Total study } \\
\%\end{array}$ & $\begin{array}{l}\text { Millen-nials } \\
\%\end{array}$ & $\begin{array}{l}\text { Gen-Xers } \\
\%\end{array}$ & $\begin{array}{l}\text { Boomers Plus } \\
\%\end{array}$ \\
\hline 1 & $\begin{array}{l}\text { Scenery and landscape, views, hillsides, horizons, } \\
\text { vegetation, etc. }\end{array}$ & 44.4 & 45.7 & 40.9 & 49.1 \\
\hline 2 & Wine quality, value, price, etc. positive references & 40.2 & 36.7 & 42.3 & 41.8 \\
\hline 3 & $\begin{array}{l}\text { Wineries/wine estates quality features, facilities, } \\
\text { variety of small to large }\end{array}$ & 27.3 & 30.9 & 26.0 & 23.6 \\
\hline 4 & $\begin{array}{l}\text { Ambience of region, tranquility, rural character, } \\
\text { clean, great climate }\end{array}$ & 27.1 & 28.2 & 25.6 & 28.2 \\
\hline 5 & $\begin{array}{l}\text { Restaurants great, food quality excellent, } \\
\text { German cuisine }\end{array}$ & 25.9 & 25.5 & 26.5 & 25.5 \\
\hline
\end{tabular}

${ }^{a}$ No significant differences at either .05 or .01 level. 
Table 9 Top 5 wine regional categories - Visitor age generation segments and wine tourism specialists vs. generalists ${ }^{a}$

\begin{tabular}{|c|c|c|c|c|c|c|c|c|c|}
\hline \multirow{2}{*}{\multicolumn{2}{|c|}{ Description of characteristic }} & \multicolumn{2}{|c|}{ Total study (\%) } & \multicolumn{2}{|c|}{ Millennials (\%) } & \multicolumn{2}{|c|}{ Generation-Xers (\%) } & \multicolumn{2}{|c|}{ Boomers Plus (\%) } \\
\hline & & Specialists & Generalists & Specialists & Generalists & Specialists & Generalists & Specialists & Generalists \\
\hline 1 & $\begin{array}{l}\text { Scenery and landscape, views, } \\
\text { hillsides, horizons, } \\
\text { vegetation, etc. }\end{array}$ & 47.7 & 42.1 & 51.1 & 41.0 & 43.3 & 39.2 & 50.0 & 48.6 \\
\hline 2 & $\begin{array}{l}\text { Wine quality, value, price, etc. } \\
\text { positive references }\end{array}$ & 43.1 & 38.0 & 42.0 & 32.0 & 42.2 & 42.4 & 47.4 & 38.9 \\
\hline 3 & $\begin{array}{l}\text { Wineries/wine estates quality } \\
\text { features, facilities, variety } \\
\text { small/large }\end{array}$ & 30.6 & 24.9 & 36.4 & 26.0 & 27.8 & 24.8 & 23.7 & 23.6 \\
\hline 4 & $\begin{array}{l}\text { Ambience of region, tranquility, } \\
\text { rural character, clean, } \\
\text { great climate }\end{array}$ & 26.4 & 27.6 & 25.0 & 31.0 & 24.4 & 26.4 & 34.2 & 25.0 \\
\hline 5 & $\begin{array}{l}\text { Restaurants great, food quality } \\
\text { excellent, German cuisine }\end{array}$ & 26.4 & 25.6 & 27.3 & 24.0 & 26.7 & 26.4 & 23.7 & 26.4 \\
\hline
\end{tabular}

${ }^{a}$ No significant differences at either .05 or .01 level.

Generation-Xers ranked "wine quality" first and "scenery and landscape" second. The mentioned regional characteristics of ranks 3-5 are pretty similar between all age generations as well. For the "specialist wine tourists" whose primary motivation to visit the Barossa wine region is the wine itself the first two characteristics "scenery and landscape" and "wine quality" got even higher scores than for the "generalist wine tourists." Yet, no significant differences appeared at either .05 or .01 level. We conclude that neither age generational cohort nor degree of wine tourism specialization is a strong indicators of wine regional characteristics perception.

\section{Conclusions, implications, limitations, and recommendations}

This study is the first to link destination image attributes to visit motivations and the age generational cohorts of wine tourists and to use an experiential research approach in the process. This research method has been advocated by Dodd and Gustafson (1997) and previously applied in the wine tourism context by Bruwer and Alant (2009).

The study further contributes by closing the gap between the motivational drivers for wine tourists and actual consumption of the core wine tourism product (Ravenscroft and van Westering, 2001). The segmentation of wine tourists in different age generational cohorts' stages is not new per se but gives deeper insights into tourists' motivations. Our initial assumption that there are profound differences between wine tourists' motivations belonging to different age generational cohorts was not proven, but this finding in itself also contributes to the knowledge base.
The study results show that wine tourists are a highly attractive group of consumers as they are well-educated, affluent, and eager to buy when they experience "pleasure." The beauty of the landscape is the most important regional characteristic that wine tourists perceive. Moreover, their main motivations to visit the region are predominantly of a hedonic nature. They make their decision to visit the region quite spontaneously which supports the assumption that wine tourists show hedonic behavior.

The strong impact of the natural landscape underlines the premise that an experiential research approach can yield valuable insights and sheds new light on the fact that a memorable experience for a wine tourist does not only evolve inside the winery's cellar door. In the process, it exposits what could be unique selling points for marketing differently positioned wine regions. Therefore, strong co-operation between tourist agencies and wineries is recommended in order to increase the overall hedonic experience of the tourists within the region and within the cellar doors.

The study results also show that it is important for wineries to do more than just selling wine. They have to create hedonic experiences such as wine tastings, events, etc. The atmosphere and immediate surroundings of the winery are extremely important to attract tourists to visit the winery because their visit is often not planned in detail and quite impulsive. It is also important to train the winery staff to provide an extraordinary guest service as the customers' experience is crucial for tourists' motivation to spend time and to buy wine. Also, wineries do not have to take into account the age generational cohorts for addressing wine tourists in promotional campaigns differently, 
except perhaps for those travelling with children under the legal drinking age of 18 years.

The research was conducted almost exclusively on wine drinkers who visited cellar doors on a wine route in a wine region and this is a limitation in the sense that similar information on non-wine drinkers who also visited the region, was not obtained. The data stems only from one Australian wine region and can therefore not be seen as representative for Australia and wine regions in other countries. Furthermore, many tourists came from outside of South Australia but no information was obtained about their psychographic (lifestyle) variables and sources of information used about the wine region and wineries. This is a limitation as this information would be helpful to better target promotional campaigns.

More research needs to be conducted on non-wine drinkers that visit the wine region destination to see whether and how their motivations for visitation differ. Further studies in other wine regions in Australia and overseas should be conducted to compare the results with this initial study. Moreover, we recommend further segmentation of the wine tourist market using the lifestyle characteristics of tourists to attain a better understanding of the wine tourist. This should include determining whether travel parties include dependent children or not.

A more sophisticated distinction between specialist and generalist wine tourists could be obtained in future studies. Further research should develop a hedonism scale in order to measure overall hedonism (i.e. experiencing pleasure in life) as well as specific forms of hedonism related to wine tourism (such as the experience of pleasure in drinking of wine).

\section{Declaration of Conflicting Interests}

The author(s) declared no potential conflicts of interest with respect to the research, authorship, and/or publication of this article.

\section{Funding}

The author(s) received no financial support for the research, authorship, and/or publication of this article.

\section{ORCID iD}

Johan Bruwer (D) http://orcid.org/0000-0001-7568-605X

\section{References}

Alant K and Bruwer J (2010) Winery visitation sets: Intraregional spatial movement. International fournal of Wine Business Research 22(2): 191-210.

Alant Bruwer J (2004) Wine tourism behaviour in the context of a motivational framework for wine regions and cellar doors. Fournal of Wine Research 15(1): 27-37.
Asero V and Patti S (2011) Wine tourism experience and consumer behavior: The case of Sicily. Tourism Analysis: An Interdisciplinary fournal 16(4): 431-442.

Assaker G and Hallak R (2013) Moderating effects of tourists' novelty-seeking tendencies on destination image, visitor satisfaction, and short- and long-term revisit intentions. Fournal of Travel Research 52(5): 600-613.

Australian Bureau of Statistics (2015) Australian demographic statistics. Report no. 3101.0, March 2015, Australian Bureau of Statistics, Canberra: Australia. Available at: www.abs.gov.au/ausstats/abs@.nsf/mf/3101.0 (accessed 13 November 2017).

Bruwer J (2014) Consumer behaviour insights and wine. In: Charters S and Gallo J (eds) Wine Business Management. Paris, France: Pearson France, pp.145-161.

Bruwer J (2004) The love affair of generation-x consumers with the winery tasting room. The Australian and New Zealand Grapegrower Eै Winemaker 491: 19-24.

Bruwer J (2002) Marketing wine to generation X consumers through the winery cellar door. The Australian \& New Zealand Grapegrower E Winemaker 467: 67-70.

Bruwer J and Alant K (2009) The hedonic nature of wine tourism consumption: An experiential view. International Fournal of Wine Business Research 21(3): 235-257.

Bruwer J, Coode M, Saliba AJ, et al. (2013) Wine experience effects of the tasting room on consumer brand loyalty. Tourism Analysis: An Interdisciplinary fournal 8(4): 339-414.

Bruwer J, Gross MJ and Lee HC (2016) Tourism destination image (TDI) perception within a regional winescape context. Tourism Analysis: An Interdisciplinary fournal 21(2-3): 173-187.

Bruwer J and Lesschaeve I (2012) Wine tourists' destination region brand image perception and antecedents: Conceptualisation of a winescape framework. Fournal of Travel and Tourism Marketing 29(7): 611-628.

Bruwer J, Lesschaeve I and Campbell BL (2012) Consumption dynamics and demographics of Canadian wine consumers: Retailing insights from the tasting room channel. Fournal of Retailing and Consumer Services 19(1): 45-58.

Bruwer J and Thach L (2013) Wine tourists' use of sources of information when visiting a USA wine region. Fournal of Vacation Marketing 19(3): 221-237.

Byrd ET, Canziani B, Hsieh YC, et al. (2016) Wine tourism: Motivating visitors through core and supplementary services. Tourism Management 52: 19-29.

Calver SJ and Page SJ (2013) Exploring the relationship of service value, visitor knowledge and interest to visitor enjoyment at heritage attractions. Tourism Management 39: 23-36.

Carlsen J and Boksberger P (2015) Enhancing consumer value in wine tourism. Fournal of Hospitality and Tourism Research 39(1): 132-144.

Carlsen J, Dowling R and Cowan E (1998) Wine tourism marketing issues in Australia. International fournal of Wine Marketing 10(3): 23-32.

Charters S and Ali-Knight J (2002) Who is the wine tourist? Tourism Management 23(1): 311-319. 
Charters S, Fountain J and Fish N (2009) "You felt like lingering..." Experiencing "real" service at the winery tasting room. Fournal of Travel Research 48(1): 122-134.

Chen X, Bruwer J, Cohen J, et al. (2016) A wine tourist behaviour model for Australian winery cellar doors. Tourism Analysis: An Interdisciplinary fournal 21(1): 77-91.

Chen X, Goodman S, Bruwer J, et al. (2015) Beyond better wine: The impact of experiential and monetary value on wine tourists' loyalty intentions. Asia Pacific fournal of Tourism Research 21(2): 172-192.

Dhar R and Wertenbroch K (2000) Consumer choice between hedonic and utilitarian goods. Fournal of Marketing Research 37(1): 60-71.

Dimock M (2018) Defining generations: Where Millennials end and post-Millennials begin, Pew Research Center. Available at: www.pewresearch.org/fact-tank/2018/03/ 01/defining-generations-where-millennials-end-andpost-millennials-begin/ (accessed 23 March 2018).

Dinas E and Stoker L (2014) Age-period-cohort analysis: A design-based approach. Electoral Studies 33: 28-40.

Dodd TH and Gustafson AW (1997) Product, environmental, and service attributes that influence consumer attitudes and purchases at wineries. Fournal of Food Products Marketing 4(3): 41-59.

Douglas N, Douglas N and Derrett R (2001) Special Interest Tourism: Context and Cases. Milton, QLD: Australia, John Wiley and Sons.

Famularo B, Bruwer J and Li E (2010) Region of origin as choice factor: Wine knowledge and wine tourism involvement influence. International fournal of Wine Business Research 22(4): 362-385.

Fodness D (1994) Measuring tourist motivation. Annals of Tourism Research 21(3): 555-581.

Galloway G, Mitchell R, Getz D, et al. (2008) Sensation seeking and the prediction of attitudes and behaviours of wine tourists. Tourism Management 29(5): 950-966.

Getz D and Brown G (2006) Critical success factors for wine tourism regions: A demand analysis. Tourism Management 27(1): 146-158.

Getz D, Dowling R, Carlsen J, et al. (1999) Critical success factors for wine tourism. International fournal of Wine Marketing 11(3): 20-43.

Gill D, Byslma B and Ouschan R (2007) Customer perceived value in a cellar door visit: The impact on behavioural intentions. International fournal of Wine Business Research 19(4): 257-275.

Gnoth J (1997) Tourism motivation and expectation formation. Annals of Tourism Research 24(2): 283-304.

Goossens C (2000) Tourism information and pleasure motivation. Annals of Tourism Research 27(2): 301-321.

Grappi S and Montanari (2011) The role of social identification and hedonism in affecting tourist re-patronizing behaviours: The case of an Italian festival. Tourism Management 32: 1128-1140.

Gursoy D, Spangenberg ER and Rutherford DG (2006) The hedonic and utilitarian dimensions of attendees' attitudes towards festivals. Fournal of Hospitality and Tourism Research 30(3): 279-294.
Hall CM, Sharples L, Cambourne B, et al. (2000) Wine Tourism Around the World. Oxford: Butterworth Heinemann.

Higgins L and Wolf MM (2016) Millennials as luxury wine buyers in the United States? International fournal of Wine Business Research 28(3): 190-205.

Hirschman EC and Holbrook MB (1982) Hedonic consumption: Emerging concepts, methods and propositions. Fournal of Marketing 46(3): 92-101.

Holbrook MB and Hirschman EC (1982) The experiential aspects of consumption: Consumer fantasies, feelings, and fun. Fournal of Consumer Research 9(2): 132-140.

Holland T, Smit B and Jones GV (2014) Toward a conceptual framework of terroir tourism: A case study of the Prince Edward County, Ontario wine region. Tourism Planning and Development 11(3): 275-291.

Hosany S and Gilbert D (2010) Measuring tourists' emotional experience toward hedonic holiday destinations. Fournal of Travel Research 49(4): 513-526.

Jackson V, Stoel L and Brantley A (2010) Mall attributes and shopping value: Differences by gender and generational cohort. Fournal of Retailing and Consumer Services 18: $1-9$.

Johnson GR (1998) Wine tourism in New Zealand: A national survey of wineries 1997. Unpublished Diploma in Tourism Dissertation, University of Otago, New Zealand.

Kim JH (2014) The antecedents of memorable tourism experiences: The development of a scale to measure the destination attributes associated with memorable experiences. Tourism Management 44: 34-45.

Laesser C and Crouch GI (2006) Segmenting markets by travel expenditure patterns: The case of international visitors to Australia. Fournal of Travel Research 44(4): 397-406.

Lothian A (1999) Landscape and the philosophy of aesthetics: Is landscape quality inherent in the landscape or in the eye of the beholder? Landscape and Urban Planning 44(4): 177-198.

MacDonald JB, Saliba AJ and Bruwer J (2013) Wine choice and drivers of consumption explored in relation to generational cohorts and methodology. Fournal of Retailing and Consumer Services 20(3): 349-357.

Marzo-Navarro M and Pedraja-Iglesias M (2009) Wine tourism development from the perspective of the potential tourist in Spain. International fournal of Contemporary Hospitality Management 21(7): 816-835.

McKercher B and Tse TSM (2012) Is intention to return a valid proxy for actual repeat visitation? Fournal of Travel Research 51(6): 671-686.

McKercher B and Wong DYY (2004) Understanding tourism behaviour: Examining the combined effects of prior visitation history and destination status. Fournal of Travel Research 43(2): 171-179.

Meng F and Xu Y (2012) Tourism shopping behavior: Planned, impulsive or experiential? International fournal of Culture, Tourism and Hospitality Research 6(3): 250-265.

Mitchell R and Hall CM (2004) The post-visit consumer behaviour in New Zealand of winery visitors. Fournal of Wine Research 15(1): 39-49. 
Nicolau JL and Mas FJ (2006) The influence of distance and prices on the choice of tourist destinations: The moderating role of motivations. Tourism Management 27(5): 982-996.

Noble SM, Schewe CD and Kuhr M (2004) Preferences in health care services and treatment: A generational perspective. Fournal of Business Research 57(1): 1033-1041.

Nohl W (2001) Sustainable landscape use and aesthetic perception: Preliminary reflections on future landscape aesthetics. Landscape and Urban Planning 54(1-4): 223-237.

Oh H, Fiore AM and Jeoung M (2007) Measuring experience economy concepts: Tourism applications. Fournal of Travel Research 46(2): 119-132.

Opperman M (2000) Tourism destination loyalty. Fournal of Travel Research 39(1): 78-84.

Pan FC, Su SJ and Chiang CC (2008) Dual attractiveness of winery: Atmospheric cues on purchasing. International Fournal of Wine Business Research 20(2): 96-110.

Pew Research Center (2015) The whys and hows of generations research. Available at: www.people-press.org/2015/ 09/03/the-whys-and-hows-of-generations-research/ Washington DC: USA, (accessed 23 March 2018).

Pikkemaat B, Peters M, Boksberger P, et al. (2009) The staging of experiences in wine tourism. Fournal of Hospitality Marketing and Management 18(2-3): 237-253.

Pine BJ and Gilmore JH (1998) Welcome to the experience economy. Harvard Business Review 76(4): 97-105.

Prayag G and Ryan C (2011) Antecedents of tourists' loyalty to Mauritius: The role and influence of destination image, place attachment, personal involvement, and satisfaction. Fournal of Travel Research 51(3): 342-356.

Quadri-Felitti D and Fiore AM (2012) Experience economy constructs as a framework for understanding wine tourism. Fournal of Vacation Marketing 18(1): 3-15.

Quintal VA, Thomas B and Phau I (2015) Incorporating the winescape into the theory of planned behaviour: Examining 'New World' wineries. Tourism Management 46: 596-609.

Ravenscroft N and van Westering J (2001) Wine tourism, culture and the everyday: A theoretical note. Tourism and Hospitality Research 3(2): 49-162.
Roberts L and Sparks B (2006) Enhancing the wine tourism experience: The customers' viewpoint. In: Carlsen J and Charters S Global Wine Tourism: Research, Management and Marketing. Cambridge: CAB International, pp.47-55.

Saliba AJ, Bruwer J and MacDonald JB (2015) Consumption metrics of Chardonnay wine consumers in Australia. International fournal of Wine Research 7: $1-11$.

Schiffman L, O'Cass A, Paladino A, et al. (2011) Consumer Behaviour. 5th ed. Frenchs Forest: Pearson Australia.

Shani A, Reichel A and Croes R (2012) Evaluation of segment attractiveness by risk-adjusted market potential: First-time vs. repeat visitors. Fournal of Travel Research 51(2): 166-177.

Snepenger D, Snepenger M, Dalbey M, et al. (2007) Meanings and consumption characteristics of places at a tourism destination. Fournal of Travel Research 45(3): 310-321.

Spangenberg ER, Voss KE and Crowley AE (1997) Measuring the hedonic and utilitarian dimensions of attitude: A generally applicable scale. Advances in Consumer Research 24(1): 235-241.

Veenhoven R (2003) Hedonism and happiness. Fournal of Happiness Studies 4(4): 437-457.

\section{Author Biographies}

Johan Bruwer is a Professor of Marketing in the School of Marketing at the University of South Australia in Adelaide, Australia and Adjunct Professor in the Departmenent of Management, Marketing and Entrepreneurship at the University of Canterbury in Christchurch, New Zealand.

Edith Rueger-Muck is a Professor of Marketing at the University of Applied Sciences Ludwigshafen in Ludwigshafen, Germany. 